\title{
ETIKK I FORSKNING
}

Om forhåndsgodkjenning av forskningsprosjekter i regionale etiske komiteer

Av Knut W. Ruyter, Avdelingsdirektør REK sørøst, Det medisinske fakultet, professor, dr. philos, Det teologiske fakultet, Universitetet i Oslo

Det har skjedd mye på tjue år. I 1989 kunne Eli Haugen Bunch fastslå at det ikke hadde blitt fremlagt ett eneste forskningsprosjekt av en sykepleier (1). De regionale komiteene for medisinsk forskningsetikk ble opprettet i 1987 med en forløper i Forskningsrådet fra 1977 (2). Som en av pionerene innen sykepleieforskning anbefalte Eli Haugen Bunch at sykepleiere måtte få kunnskap om etiske prinsipper og lære seg å resonnere etisk på en logisk måte (1). Hun fremhevet særlig et ufravikelig krav om skriftlig informert samtykke, full åpenhet om alt som grunnlag for et gyldig samtykke, tilegnelse av forskningskompetanse blant sykepleiere og behovet for litteraturgjennomgang (1).

Tjue år senere ser bildet helt annerledes ut. Nå behandles forskningsprosjekter fra faggruppen sykepleiere i hvert møte. Utdanningene forutsetter at det skal gjøres forskningsbaserte aktiviteter, og Sykepleien Forskning har omtale av flere doktoravhandlinger i hvert nummer. De fleste av disse viser at virkeligheten er vanskeligere enn prinsipper og logisk tenkning, og at det må gjøres tilpasninger for å gjøre et prosjekt så etisk forsvarlig som mulig. Det som kjennetegner sykepleie som egen profesjon er nærheten til pasienten gjennom hele forløpet av kontakten med helsevesenet. Dette er antakelig grunnen til at mange sykepleieforskere er motivert til å studere de pasientgrupper som er mest sårbare, og som derfor også ofte kommer påkant med krav til samtykke. Det være seg hjerteopererte pasienter, gamle mennesker med hoftebrudd, eldre pleietrengende, slagpasienter, premature barn, kreftpasienter, psykisk syke, for bare å nevne noen fra de sist omtalte doktoravhandlinger.

\section{> EN LOV, EN POSTKASSE}

Fra 1. juli 2009 gjelder Lov om medisinsk og helsefaglig forskning (3). Hovedhensikten med loven er å fremme «god og etisk forsvarlig medisinsk og helsefaglig forskning», og sørge for å forenkle godkjenningsprosedyrene for forskere. De viktigste endringene er knyttet til at loven aksepterer bruk av bredt samtykke, og tillater eksplisitt unntak fra samtykke. På forenklingssiden er oppgaver overført til REK fra Helsedirektoratet (dispensasjon fra taushetsplikt og opprettelse av forskningsbiobanker) og fra Datatilsynet (bruk av helseopplysningerl.

De viktigste andre kildene for forskningsetikk som forskere bør kjenne til er Helsinkideklarasjonen (4) og tilleggsprotokollen for biomedisinsk forskning (5). Det må være riktig å si at loven kodifiserer Helsinkideklarasjonen, mens tilleggsprotokollen utdyper den på noen viktige områder. spesielt i «explanatory report». Det gis for eksempel en utdypende forklaring og utlegning til hva som menes med en forsvarlig avveining av ulike hensyn. Som for eksempel hvorvidt samfunnsinteressene klart overstiger ulempene for den enkelte deltaker.

\section{$>$ HVA SKAL DET SøKES OM GODKJENNING FOR?}

Helseforskningsloven forutsetter at all (medisinsk og helsefagligl forskning som involverer mennesker skal forhåndsgodkjennes av REK. Det omfatter forskning på helseopplysninger (kap. 7) og forskning på humant biologisk materiale (kap. 6).

\section{GRUNNLAG OG VEILEDNING}

Grunnlaget for den etiske vurdering lar seg relativt enkelt beskrive, selv om selve vurderingen av de enkelte elementene ikke behøver å være enkel.

Det er vesentlig å være seg bevisst at selv om samtykke fremheves som hovedregel, er den ikke den eneste regelen. Det er en rekke elementer som skal være vurdert som tilfredsstillende og forsvarlig før man eventuelt skal vurdere å spørre 
om deltakelse. Det gjelder vitenskapelig protokoll og metode, avveining av nytte og ulempe, og om det er tillatelig å forske på eller med den gruppen man har sett seg ut.

\section{> GODT FORSKNINGSDESIGN}

For komiteen er det av stor viktighet å få innsikt i det forskningsdesign som er valgt. Jeg er klar over at en del sykepleieforskere har følt seg stemoderlig behandlet av REK som følge av hva som oppfattes som fordomsfulle holdninger til en del kvalitativ forskning. Jeg vil tydelig fremheve at REK skal respektere forskningstradisjoner som benytter kvalitative metoder, eller undersøker alternative kunnskapssyn. Det fordrer imidlertid at slike prosjekter er utformet som et forskningsdesign, med gode beskrivelser av utvelgelse, innsamlingsmetode, fremgangsmåter og grunnlag for analyse og fortolkning. Det skal for eksempel ikke være tvil om at en observasjonsstudie er en anerkjent forskningsmetode innen visse felt, og for spesifikke formål. Den nasjonale forskningsetiske komité for medisin og helsefag (NEM) har også høsten 2009 utgitt en veileder for kvalitativ forskning. Den er ment som en håndsrekning til blant annet sykepleieforskere og skal hjelpe medlemmer av REK til å vurdere kvalitativ forskningsdesign på sine egne premisser.

\section{$>$ PREFERANSEORDNING}

Et annet viktig moment er vurderingen av hvem som egner seg som deltaker i forskning. Den tyske filosofen Hans Jonas har beskrevet dette som et preferanseordningssystem, eller som regelen om den nedstigende rekke (5) som setter navn på et viktig anliggende i Helsinkideklarasjonen. Hovedpunktet er at en forsker som trer inn i gråsoner, hvor personer ikke kan oppfylle krav til samtykke og frivillighet, må bevege seg med stor etisk varsom- het. Varsomheten beskriver han slik: «Jo fattigere på kunnskap, motivasjon og bestemmelsesfrihet subjektgruppen er, desto mer varsomt, ja, motvillig, skulle dette reservoar benyttes, og desto mer tvingende må derfor den oppveiende rettferdiggjørelsen gjennom målet være» (ibid.). Sykepleieforskning beveger seg ofte i disse gråsonene. Det er derfor av sentral betydning at det først stilles spørsmål om det er etisk forsvarlig å involvere den gruppen man ønsker å studere nærmere. Det innebærer å teste motvillighet. NEM har vært spesielt opptatt av at dette må være særlig nøye vurdert i forbindelse med studentoppgaver. Det betyr ikke at det ikke kan eller skal gjøres, men det betyr at man skal ha ytt etisk motstand. Hvis motstanden kan overvinnes, kreves det som Jonas kaller en «oppveiende rettferdiggjørelse»: man må kunne vise til gode grunner for å kunne gjøre det. En av forutsetningene som Jonas stiller er at studien «må ha å gjøre med deres egen lidelse» libid., jf. Helsinkideklarasjonen).

\section{> PROPORSJONALITET}

Dernest skal det foretas en omhyggelig avveining av nytte og risiko, som det tidligere het i Helsinkideklarasjonen. EU's tilleggsprotokoll gir utfyllende veiledning om hva som kan avveies og hvordan (4). Nytte omtales som fordeler for den enkelte deltaker, grupper av personer, samfunnet eller utvikling av vitenskapelig kunnskap som sådan. Det er viktig å legge merke til at fordelene skal være «påregnelige» (§ 22 i helseforskningsloven). Det er ikke tilstrekkelig at man ikke kan utelukke at det kan komme til nytte en eller annen gang. Veiledningen er tilsvarende tydelig på at risiko ikke skal forstås snevert, men omfatte ubehag, ulempe og endog praktiske vansker. Veiledningen er særlig opptatt av at ulemper i hovedsak skal avveies i forhold til den enkelte deltaker, men den er seg også bevisst 
at det kan være ulemper for grupper av personer, for eksempel i form av fare for diskriminering og stigmatisering.

Å foreta slike avveininger gjelder alle prosjekter, også der det skal innhentes samtykke. Avveiningen er imidlertid helt avgjørende i de tilfeller hvor det anses som uforholdsmessig vanskelig å innhente samtykke, eller hvor det ikke (lenger) er mulig. I slike tilfeller forutsettes det at alle former for risiko skal bedømmes som «ubetydelig» (§ 19). For personer som ikke kan samtykke, eller hvor det er uforholdsmessig vanskelig å innhente samtykke, skal man ikke kunne tenke seg at desto større nytte man kan påregne, jo større risiko kan man ta. Proporsjonalitet støter på en skranke. Det er endog slik at man anmodes om å tenke gjennom ulike måter som kan redusere ulempene for den enkelte. Man kan vurdere om informasjon kan gis generelt for å gi mulighet for at personer kan reservere seg fra deltakelse.

\section{> SAMTYKKE}

Når de ovenfor nevnte forhold er vurdert som etisk forsvarlige, skal samtykke vurderes. På papiret er kravet enkelt. I virkeligheten er det både komplisert og sårbart. Det er en av grunnene til at Helsinkideklarasjonen så sterkt har fremhevet at prosjektleder beholder alt ansvar selv om det er innhentet samtykke. Innen forskning som er kombinert med behandling ( $\S 22$ i helseforskningsloven) oppstår det misforståelser når pasienter blir spurt om å delta. I en nylig studie av slagpasienter fremkom det at pasienter blir veldig usikre av å bli spurt. De leste det som at legen overlater ansvaret til pasienten. En pasient uttrykte seg slik: "Jeg mener faktisk at det er veldig lite å spørre om ... etter min mening burde vitenskapen ha gjort tilstrekkelig fremskritt ... i forhold til dette, så hvorfor skal de spørre pasienter som ikke har peiling, uansett?» (6).
Dette illustrerer at det ofte er et misforhold mellom hva lovgiver mener at samtykke skal sikre (selvbestemmelse, kontroll med bruk av data om en selv), og hvordan forespørsler og tillatelser blir oppfattet av den enkelte i ulike situasjoner. Ikke minst innen sykepleieforskning vil forskning ofte omhandle pasienter som er i sårbare situasjoner og hvor samtykkeinstrumentet er av begrenset betydning, etisk sett, om ikke rettslig. Den engelske filosofen Onora O'Neill påpeker at mange pasienter som deltar i forskning ikke oppfyller grunnforutsetningene for samtykke (7). Den vesentlige innsikten som 0'Neill trekker med seg fra dette er at samtykke egentlig spiller en (svært) beskjeden og begrenset rolle i å beskytte den enkeltes selvbestemmelse (ibid.). Minst like viktig er at hun fremhever at det kognitivt er «systematiske begrensninger» i hvordan særlig pasienter kan ta stilling til forslag om ulike valgmuligheter. De kan ha problemer med å overskue konsekvensene for seg selv, fordi den enkeltes blikk ofte er nærsynt. Det gjør at forslag ofte fremstår som ugjennomtrengelige eller utydelige (ibid.) for den enkelte. Dette har gjort at blant annet O'Neill fremhever at samtykkets viktigste funksjon er at den gir uttrykk for tillit, og at den enkelte på det grunnlaget gir en form for tilsagn til deltakelse. Dette understreker betydningen av at ansvaret alltid blir værende hos forsker.

Ved å fremheve denne konteksten ønsker jeg å understreker at «arbeidet» med samtykke i hovedsak ligger hos forsker. Det frigjør selvfølgelig ikke forsker fra å kjenne til de relativt detaljerte regler som gjelder for innhenting av samtykke, med de unntak som gjelder. For de aller fleste grupper - og individer $\mathrm{i}$ disse gruppene - er det mulig å tilrettelegge rekruttering, informasjon og deltakelse på måter som kan forbedre og heve kvaliteten på samhandlingen mellom pasient og forsker. Da 
må samtykke innebære en prosess som innbyr til delaktighet i den grad det er mulig å få til, ikke som en skriftlig engangshendelse.

Denne måten å vurdere samtykke på plasserer ansvaret hos forsker og gjør krav på at forskere må utvise kvalifisert skjønn (8). Bevisbyrden for forsvarlighet ligger hos forsker, ikke i underskriften på informasjonsskrivet.

\section{> DISPENSASJON FRA TAUSHETSPLIKT}

Det kan være aktuelt for sykepleieforskere å innhente dispensasjon fra taushetsplikt. Det kan relatere seg til studier hvor man har behov for tilgang til taushetsbelagte opplysninger, for eksempel i journal. Det mest kritiske området for godkjenning har vært i forhold til deltakende observasjon.

Hovedregelen er at det er adgang til å få dispensasjon til å benytte helseopplysninger som allerede er innsamlet i helsetjenesten til forskning (§ 35). Forutsetningen er at forsker kan sannsynliggjøre at forskningen er av «vesentlig interesse for samfunnet»og at «hensynet til deltakernes velferd og integritet er ivaretatt» ( $\S 35$ ). Det er det samme vurderingstema som er drøftet ovenfor. I klartekst innebærer det at vurderingen ikke skal basere seg på om samtykke kan innhentes, men om avveiningen er forsvarlig. Lovgiver, så vel som forskningsetikken, har imidlertid vært opptatt av at man ikke skal foretrekke dispensasjon av bekvemmelighetsgrunner. Derfor blir det ofte lagt til grunn at det skal være «uforholdsmessig vanskelig» å innhente samtykke. Uforholdsmessig vanskelig er ingen statistisk størrelse. Det avhenger av ulike faktorer og konkrete sammenhenger av kontekst, slik som antall, tidsaspekt, type forskning og så videre.

Det er imidlertid ikke i forhold til dispensasjon fra allerede innsamlede opplysninger at sykepleiere har støtt på vansker. Det gjelder i særdeleshet deltakende observasjon. Helsedirektoratet, som har behandlet slike saker frem til 30.6.2009, hadde som praksis at det skal innhentes samtykke hvis det kan (uten uforholdsmessige vansker) innhentes. Dette fikk store konsekvenser for observasjonsstudier. Kravet til samtykke fra den enkelte deltaker, innebar at flere prosjekter ble umulig å gjennomføre. Prosjektene har i hovedsak dreid seg om observasjoner av pasienter/beboere i ulike helseinstitusjoner, fra psykiatriske institusjoner via enheter for døende til sykehjem. Stort sett har hensikten vært å observere kvalitet og livsvilkår i forhold til hvordan pasienter/beboere ivaretas i samhandling med helsepersonell. Av og til er det uttrykt behov for å studere de lukkede rom for eventuelt å avdekke uheldig praksis og så videre.

Helseforskningsloven forholder seg ikke til deltakende observasjon som noe annet enn «allerede innsamlet». Det gjør heller ikke helsepersonelloven. Det gjør det vanskelig å vurdere når det skal søkes om dispensasjon fra taushetsplikten. Uansett forutsettes at deltakende observasjon log feltarbeid) anses som en anerkjent vitenskapelig metode for å undersøke den sosiale verden slik den foreligger i kontekster med sammensatt sosial interaksjon (9). Det er verdt å fremheve at det ikke minst var sykepleieforskere som anså den svært egnet til de forskningsformål som de var opptatt av. Timothy Diamond omtaler det slik: «Jeg bestemte meg da ... for å gå på innsiden for å erfare arbeidet selv» (10). Man må derfor først stille seg spørsmål om det er nødvendig å innhente dispensasjon for den type deltakende observasjon som skal gjøres. Det kan neppe være nødvendig hvis forsker vil observere beboere på sykehjem i fellesrom. Til nød kan det skje at observatør kan overhøre private og kanskje også sensitive opplysninger, men disse kan neppe klassifiseres som taushetsbelagte. Dette kan selvfølgelig forholde seg helt annerledes hvis man $\emptyset n s k e r$ å observere i situasjoner hvor taushetsbe- 
lagte opplysninger er tilgjengelige og vil bli omtalt. For eksempel i stellesituasjoner med døende eller på akuttpsykiatriske avdelinger. For det andre må man betenke at deltakende observasjon ofte er opptatt av samhandling mellom grupper av klienter og grupper av helsepersonell. Det gjør at observasjoner også må vurderes annerledes med tanke på eventuell sårbarhet og krenkelse. For det tredje gir dispensasjon mulighet for innsyn og åpenhet i ofte lukkede rom. Denne åpenheten bidrar i seg selv til ivaretakelse av dem som blir observert. Avvisning av dispensasjon fra taushetsplikten har den utilsiktede og uheldige virkning at det kan bidra til å beskytte helsepersonell mot kritikk og sementere uforsvarlig praksis. Det er taushetspliktens janusansikt: den kan brukes til å beskytte andre enn den er ment å beskytte. Og når de fleste observasjonsstudier nettopp omhandler sårbare pasienteller beboergrupper, er det egentlig et stort gode for akkurat disse gruppene at deres hjelpere blir kikket i kortene.

\section{> HVA SKAL IKKE FREMLEGGES FOR REK}

I henhold til den nye helseforskningsloven er det i det minste tre vurderingstema som bestemmer om et prosjekt er fremleggelsespliktig eller ikke. Det gjelder formål, kvalitetssikring og anonyme opplysninger. Det er vanskelig å unngå at det finnes gråsoner, hvor det kan være vanskelig å avgjøre om det skal til REK eller ikke. Hvis det ikke skal til REK faller det imidlertid ikke i et etisk eller rettslig tomrom. Bruk av personopplysninger skal da til Datatilsynet. Kvalitetssikringsprosjekter skal ha godkjenning fra institusjon. Ved bruk av anonyme opplysninger er det ikke lenger noe personvern å beskytte.

\section{Formål}

Helseforskningsloven forutsetter at fremleggelse for REK gjelder «medisinsk og helsefaglig forskning» som en virksomhet «som utføres med vitenskapelig metodikk for å skaffe til veie ny kunnskap om helse og sykdom» (§ 4a).

Det har tidligere vært relativt bred praksis at all bruk av helseopplysninger og all forskning utført av helsepersonell eller ved helseinstitusjoner, ble behandlet av REK. Det er imidlertid ikke lenger tilfelle. Man kan godt benytte helseopplysninger til forskning med andre formål, for eksempel samfunnsvitenskapelige, pedagogiske, antropologiske, organisatoriske, samfunnsøkonomiske og så videre. Det er da heller ikke avgjørende om helseopplysningene er mange og sensitive. Det er heller ikke i seg selv avgjørende om forskningen utføres av helsepersonell eller gjøres i helseinstitusjoner.

Jeg vil tro at det også i sykepleieforskning kan være vanskelig å bestemme om formålet er oppfylt. Dette lar seg best illustrere ved eksempler. Et prosjekt hadde som formål å forbedre tjenester for «svake eldre» innen kommunehelsetjenestens bestiller-utførermodell. Hensikten var å få frem erfaringer fra «utførerne» med hensyn til delt forvaltning. At prosjektet benytter seg av helseopplysninger om svake eldre er i seg selv ikke tilstrekkelig til at det kan anses som helsefaglig forskning. Et annet prosjekt skulle undersøke hvordan eldre pakistanske kvinner med diabetes II lever med sykdommen i en norsk hverdag og hvordan de blir møtt og forstått av helsepersonell. I dette tilfellet er formålet heller ikke helsefaglig, selv om noen helseopplysninger inngår som indikatorer i studien. Det som kan bidra til å vanskeliggjøre bestemmelsen av formålet er at disse prosjektene - som en rekke andre - kan være relevante for helse og sykdom og endog bidra til å forbedre ulike forhold rundt sykdom, fra mestring til ivaretakelse. Jeg vil imidlertid mene at relevans ikke kan være utslagsgivende for å vurdere prosjekter etter helseforskningsloven. 


\section{Kvalitetssikring}

Kvalitetssikringsprosjekter skal ikke fremlegges for REK, uansett hva de blir betegnet som: evaluering, utvikling, internkontroll. Forutsetningen er at man kvalitetssikrer data man allerede har samlet inn og eventuelt supplerer dem med nye kliniske undersøkelser, spørreskjema, blodprøver av de samme pasienter «av samme art som ved den ordinære diagnostikk og behandling», for å sitere NEMs mal for saksbehandling i REK. På dette området har det også vært praksis for å fremlegge for REK hvis kvalitetssikring ble gjort med «vitenskapelig metodikk», og man hadde til hensikt å publisere resultatene. Det er viktig å understreke at bruk vitenskapelig metodikk ikke i seg selv er avgjørende. Jeg vil mene det er nesten meningsløst å drive kvalitetssikring hvis den ikke gjøres etter aksepterte vitenskapelige metoder og gjøres kjent gjennom publikasjon.

Ved å fastholde at det også her er formålet som er avgjørende (altså kvalitetssikring), slipper vi også den umulige oppgaven å fastsette når kvalitetssikring blir forskning. Det er bare når kvalitetssikring skal innhente nye opplysninger eller anvende nye metoder (som ikke er en del av den ordinære diagnostikk og behandling), og/eller at opplysninger skal kobles til andre registre, at denne typen forskning skal gjøres til gjenstand for fremleggelse.

\section{Anonyme opplysninger}

Forskning på anonyme opplysninger faller også utenfor REK's ansvarsområde (helseforskningsloven $\S \S$ $2,4 d, 20$ ). Det sier seg selv at dette ikke vil være mulig ved intervjuer og lignende som forutsetter at man henvender seg til og har kontakt med enkeltpersoner. Dette vil i hovedsak gjelde bruk av spørreskjema i forskning.

En forsker må først og fremst spørre seg om det er etisk forsvarlig å behandle opplysninger anonymt. Det avhenger mye av hva man etterspør. Hvis spørs- mål er sensitive - og kan trigge alvorlige reaksjoner, bør forsker ha tenkt gjennom om det i det hele tatt er forsvarlig å gjøre undersøkelsen anonymt, altså uten mulighet for rekontakt i form av beredskap og oppfølging. Det kan for eksempel dreie seg om personer som vurderer å ta sitt eget liv eller som lurer på om de trenger behandling og så videre. I noen tilfeller bør forskere ta (et visst) ansvar for hva et spørreskjema kan utløse av psykososiale belastninger.

Hvis forsker er kommet til at det er forsvarlig å behandle opplysninger anonymt, synes det klart at en utsendelse av et spørreskjema postalt som returneres uten personidentifiserbare opplysninger, faller utenfor. Hvordan forholder det seg hvis forsker selv tar direkte kontakt med potensielle informanter for å forklare prosjektet og deretter dele ut spørreskjema? Dette er det en viss uenighet om.

Nylig hadde REK til behandling en spørreskjemaundersøkelse om legekontakt og egenbehandling i forkant av sykehusinnleggelse for pasienter med astma- eller KOLS-forverring. Spørreskjema blir utdelt av personalet, men skjema inneholder ingen personidentifiserbare kjennetegn. Skjema inneholder helseopplysninger, men av liten sensitiv karakter. Komiteen kom til at forsker i dette tilfellet kun skal forholde seg til anonyme opplysninger og at spørreskjemaundersøkelsen derfor faller «utenfor komiteens mandat» (jf. Helseforskningslovens § 2).

\section{Det etisk ideelle}

Til sist kan det minnes om at de fleste forskningsområder som sykepleieforskere ønsker å studere ikke er etisk ideelle. Det gjør at forskningsetikkens ideelle forutsetninger, så vel som lovens, ofte ikke kan oppfylles. Selv om en av sykepleieetikkens pionerer startet med ufravikelige krav til samtykke og til logiske etikkresonnementer (1), viste også hennes eget forskningsarbeid behov for å tilpasse de etiske krav til de konkrete prosjekter og situasjoner. Det 
gjelder forhandlinger, deltakelse, dialogprosesser - og strevet med å finne akseptable løsninger. Og å innse at etikk er innvevd i kliniske, psykologiske og administrative aspekter som ikke gjør det enkelt å sette opp forskningsetikken på en enkel formel. Men det er som det skal være. Det er i denne virkeligheten at etikken også skal utformes, ofte etter pragmatiske og praktikable løsninger. Det er ingenting i veien for at disse løsningene kan ta vel så godt vare på den enkelte deltaker som statiske krav til forhåndssamtykke og logiske resonnementer.

\section{REFERANSER:}

1. Bunch EH. Being a member on a review board in Norway. I International Administration of Nursing, red. B. Henry. Pennsylvania: The Charles Press, 1989: 249-54.

2. Ruyter KW, Førde R, Solbakk JH, red. Medisinsk og helsefaglig etikk. 2. utg Gyldendal Akademisk, Oslo. 2007.

3. Lov om medisinsk og helsefaglig forskning. 20. juni 2008 nr. 44. [Helseforskningsloven].

4. Europarådets tilleggsprotokoll for biomedisinsk forskning til konvensjonen om menneskerettigheter og biomedisin. Se den såkalte «explanatory report». 2005. http//conventions.coe.int/ Treaty/EN/Treaties/Html/195.htm (30.10.2009).

5. Jonas H. Teknikk medisin og etikk. Ansvarsprinsippet i praksis. Oversatt av Sverre Dahl. Opprinnelig utgitt i 1985. Cappelen Akademisk Forlag, Oslo. 1997.

6. Mangset M. Autonomy and trust. Stroke patients' and their relatives' preferences. Dissertation. Oslo: Department of geriatric medicine. University of Oslo, 2008.

7. O'Neill 0. Autonomy and trust in bioethics. Cambridge University Press, Cambridge. 2002.

8. Hem MH, Heggen K, Ruyter KW. Questionable requirement for consent in observational research in psychiatry. Nursing Ethics 2007:41-53.

9. Chambliss DF, Schutt RK. Making sense of the social world. Methods of investigation. 3. ed. Pine Forge, London. 2009. 10. Diamond T. Making gray gold: narratives of nursing home care. University Press, Chicago. 1992.

For videre studium se Forskningsetisk Bibliotek (Fbib) på hjemmesiden til De nasjonale forskningsetiske komiteer: www.etikkom.no. 